J. Perinat. Med. $16(1988) 123$

\section{Uric acid levels: a useful index of the severity of preeclampsia and perinatal prognosis}

\author{
Liliana Susana Voto, Ricardo Illia, Héctor A. Darbon-Grosso, Francisco Uranga \\ Imaz, and Miguel Margulies
}

Second Chair of Obstetrics, Buenos Aires University School of Medicine, Argentina

\section{Introduction}

In 1917 SLEmons and Bogert [8] were the first to report an association between serum uric acid (SUA) levels and preeclampsia (PE) and in 1934 STANDER and CADDEN [9] first demonstrated a correlation between SUA concentration and the severity of PE. Since then numerous articles have been published which conclude that elevated uricemia in hypertensive pregnancies is associated with poor perinatal results.

The mechanism that produces this elevation of SUA concentration has not been clearly defined yet, but as SAGEN [6] and DumONT [2] have suggested, it may result from increased blood lactate levels due to anaerobic metabolism of the uteroplacental unit. An increased SUA concentration may also be affected by impaired uric acid clearance caused by maternal hemoconcentration [4].

The aim of our study was to analyze the possible correlation between the highest levels of SUA observed in hypertensive pregnant patients during the third trimester of gestation, the severity of PE and the perinatal outcome.

\section{Material and methods}

Maximum concentrations of uricemia were selected in 215 hypertensive pregnant women during the third trimester of pregnancy. Of these 215 patients, 100 had mild PE, 25 had severe PE, 70 had essential hypertension (EH) and 20 had $\mathrm{EH}$ and superimposed $\mathrm{PE}(\mathrm{EH}+\mathrm{PE})$. We categorized hypertension in pregnancy as mild in the range

\section{Curriculum vitae}

Liliana Susana Voto, M.D. was born in Buenos Aires, Argentina in 1949. She graduated from the Buenos Aires University School of Medicine with honors in 1973. She has received several awards for research in her speciality of obstetrics. These have been granted by the University of Buenos Aires and the

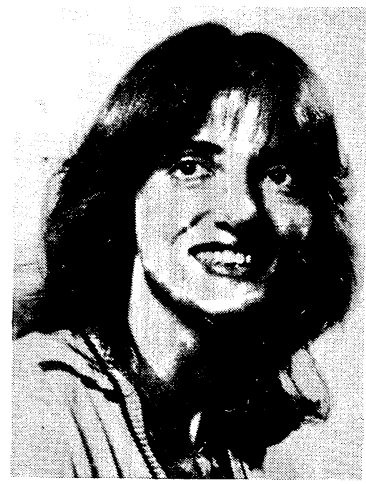
National Academy of Medicine among other institutions. Currently, she is an Assistant Professor and chief of the Research Division for the Second Chair of Obstetrics, University of Buenos Aires. Her fields of interest include hypertension in pregnancy, Rh hemolytic disease and intrauterine therapy.

140/159 torr systolic and 90/99 torr diastolic and as severe if blood pressure equalled or exceeded 160 torr systolic and 100 torr diastolic.

Mean uricemia and the occurrence of SUA levels of $6 \mathrm{mg} \%$ or higher were estimated for each group of patients. The results obtained were then correlated with perinatal results.

\section{Results}

Table I demonstrates mean SUA levels for each group. SUA values were significantly higher in patients with severe $\mathrm{PE}$ and with $\mathrm{EH}+\mathrm{PE}$ when compared with the other groups. 
Table I. Mean maximum uricemia values (mg\%) during the third trimester of gestation in hypertensive pregnant women.

\begin{tabular}{llll}
\hline Preeclampsia & \multicolumn{3}{c}{ Hypertension } \\
\hline $\begin{array}{l}\text { Mild } \\
(\mathrm{N}=100)\end{array}$ & $\begin{array}{l}\text { Severe } \\
(\mathrm{N}=25)\end{array}$ & $\begin{array}{l}\text { Essential } \\
(\mathrm{N}=70)\end{array}$ & $\begin{array}{l}\text { Essential + preeclampsia } \\
(\mathrm{N}=20)\end{array}$ \\
\hline $4.845 \pm 1.34$ & $6.22 \pm 1.30$ & $4.95 \pm 1.22$ & $6.091 \pm 1.53$ \\
\hline Analysis of variance $\mathrm{p}<0.05$ & $\left.\begin{array}{l}\text { SP vs MP vs EH } \\
\mathrm{EH}+\mathrm{PE} \text { vs } \mathrm{MP} \text { vs } \mathrm{EH}\end{array}\right\} \mathrm{p}<0.05$
\end{tabular}

Table II. Occurrence of uricemia $\geq 6 \mathrm{mg} \%$ during the third trimester of gestation in hypertensive pregnant women.

\begin{tabular}{|c|c|c|c|c|c|c|c|c|}
\hline \multirow[t]{3}{*}{ Uricemia } & \multicolumn{4}{|c|}{ Preeclampsia } & \multicolumn{4}{|c|}{ Hypertension } \\
\hline & \multicolumn{2}{|c|}{ Mild } & \multicolumn{2}{|c|}{ Severe } & \multicolumn{2}{|c|}{ Essential } & \multicolumn{2}{|c|}{ Essential + preeclampsia } \\
\hline & $\mathrm{N}$ & $\%$ & $\mathrm{~N}$ & $\%$ & $\mathrm{~N}$ & $\%$ & $\mathrm{~N}$ & $\%$ \\
\hline $\begin{array}{l}\geq 6 \\
<6\end{array}$ & $\begin{array}{l}18 \\
82\end{array}$ & $\begin{array}{l}18 \\
82\end{array}$ & $\begin{array}{l}15 \\
10\end{array}$ & $\begin{array}{l}60 \\
40\end{array}$ & $\begin{array}{l}13 \\
57\end{array}$ & $\begin{array}{l}18.6 \\
81.4\end{array}$ & $\begin{array}{r}11 \\
9\end{array}$ & $\begin{array}{l}55 \\
45\end{array}$ \\
\hline Total & 100 & 100 & 25 & 100 & 70 & 100 & 20 & 100 \\
\hline
\end{tabular}

Table III. Uricemia in pregnancy hypertension: perinatal results

\begin{tabular}{lllll}
\hline & Preeclampsia & \multicolumn{3}{c}{ Hypertension } \\
\cline { 2 - 5 } & Mild & Severe & Essential & Essential + preeclampsia \\
\hline $\begin{array}{l}\text { Mean gestational age at } \\
\text { delivery (weeks) }\end{array}$ & $39.03 \pm 1.49$ & $38.23 \pm 3.06$ & $39.51 \pm 1.36$ & $35.75 \pm 3.49$ \\
$\begin{array}{l}\text { Occurence of low birth weight } \\
\text { Mean birth weight (g) }\end{array}$ & $12(12 \%)$ & $4(16 \%)$ & $6(8.6 \%)$ & $8(40 \%)$ \\
\hline
\end{tabular}

For occurence of low birth weight $=\mathrm{MP}$ vs $\mathrm{EH}+\mathrm{PE} \mathrm{p}<0.05\left(\chi^{2}\right)$

For mean birth weight and gestational age $=M P$ vs SP vs EH + PE

$$
\left.\begin{array}{l}
\mathrm{SP} \text { vs } \mathrm{EH} \text { vs } \mathrm{EH}+\mathrm{PE} \\
\mathrm{EH} \text { vs } \mathrm{EH}+\mathrm{PE}
\end{array}\right\} \mathrm{p}<0.05 \text { analysis of variance }
$$

Table IV. Uricemia in pregnancy hypertension: its relation to low birth weight.

\begin{tabular}{lllll}
\hline Uricemia & Preeclampsia & \multicolumn{3}{c}{ Hypertension } \\
\cline { 2 - 5 } & Mild & Severe & Essential & Essential + preeclampsia \\
\hline$\geq 6$ & 3 & 2 & 1 & 4 \\
$<6$ & 9 & 2 & 5 & 4 \\
\hline Total & 12 & 4 & 6 & 8 \\
\hline
\end{tabular}

Independence test $\mathrm{p}<0.05$ N.S. 
The proportion of patients with SUA concentrations of $6 \mathrm{mg} \%$ or higher was significantly greater in women with severe PE and with $\mathrm{EH}+\mathrm{PE}$ than in those with mild PE and EH (table II).

Gestational age at delivery and mean birth weight were found to be significantly lower, and low birth weight for gestational age significantly higher, in the severe $\mathrm{PE}$ and $\mathrm{EH}+\mathrm{PE}$ groups than in the remaining groups (table III).

When the patients in each of the groups were analyzed in terms of uricemia equal to or higher than $6 \mathrm{mg} \%$, no correlation could be found between SUA levels and birth weight (table IV).

\section{Discussion}

REDMAN et al [5], FADEL et al [3] and VARMa [10] reported that SUA levels for PE patients were markedly elevated as compared with $\mathrm{EH}$ women, whose uricemia was in turn higher than in normal pregnant women.

Our study demonstrates that mean SUA concentration is significantly higher in severe PE $(6.22$ $\mathrm{mg} \% \pm 1.30 \mathrm{mg} \%)$ and $\mathrm{EH}+\mathrm{PE}$ patients $(6.09$ $\mathrm{mg} \% \pm 1.53 \mathrm{mg} \%)$ than in mild PE $(4.85 \mathrm{mg} \%$ $\pm 1.34 \mathrm{mg} \%)$ and $\mathrm{EH}$ patients $(4.95 \mathrm{mg} \% \pm 1.22$ $\mathrm{mg} \%$ ), where uricemia is higher than in normal pregnancy $(3.99 \mathrm{mg} \% \pm 0.99 \mathrm{mg} \%$ ) but still well below that in severe PE and $\mathrm{EH}+\mathrm{PE}$ cases.

Several authors $[1,3,4,5,6,7,10]$ have stated that hyperuricemia associated with a hypertensive pregnancy increases the incidence of intrauterine growth retardation, low birth weight and severe fetal distress.

VARMA [10] noted that in mild hypertension the prognosis for the fetus is affected. Our findings, when mean SUA levels and mean birth weight in all the groups were considered together, agreed with those reported by VARMA. When SUA levels and birth weight were studied within each group, no significant correlation was found. In our study, hyperuricemia was closely related to the severity of hypertension, and we did not find high SUA levels in women with mild hypertension.

We conclude that the determination of uric acid levels for the clinical screening of pregnancy complicated by hypertension is an easy and inexpensive method useful for the evaluation of perinatal results which are associated with the severity of the preeclamptic syndrome.

\section{Summary}

Maximum serum uric acid (SUA) levels during the third trimester of pregnancy were selected in 215 hypertensive pregnant women: 100 with mild preeclampsia (PE), 25 with severe $\mathrm{PE}, 70$ with essential hypertension (EH) and 20 with $\mathrm{EH}$ with superimposed PE $(\mathrm{EH}+\mathrm{PE})$. The increase in SUA levels was statistically significant in women with severe PE $(6.22 \mathrm{mg} \% \pm 1.30 \mathrm{mg} \%)$ and with $\mathrm{EH}+\mathrm{PE}(6.09 \mathrm{mg} \% \pm 1.53 \mathrm{mg} \%)$ when compared with values in mild PE and $\mathrm{EH}$ women $(4.85 \mathrm{mg} \%$ $\pm 1.34 \mathrm{mg} \%$ and $4.95 \mathrm{mg} \% \pm 1.22 \mathrm{mg} \%$, respectively).

A significant decrease in average gestational age at delivery and a greater percentage of small-for-gestational age newborns were observed in women with severe $\mathrm{PE}$ and $\mathrm{EH}+\mathrm{PE}$, compared with patients with mild PE and EH. No correlation within the groups was found between SUA levels and fetal weight.

To conclude, the determination of SUA concentration for the clinical screening of a pregnancy complicated by hypertension is an easy and inexpensive method for the prediction of perinatal results associated with severe PE.

Keywords: Clinical study, preeclampsia, uric acid levels.

\section{Zusammenfassung}

Der Harnsäurespiegel als brauchbarer Parameter für den Schweregrad einer Präeklampsie und seine prognostische Bedeutung

Bei 215 hypertonen Schwangeren im letzten Trimenon wurden die Maxima der Harnsäurespiegel in Beziehung zum Grad der Eklampsie gesetzt. Dabei lagen bei 100 Frauen eine leichte und bei 25 eine schwere Präeklampsie vor. 70 Frauen hatten eine essentielle Hypertonie und 20 eine essentielle Hypertonie mit Pfropfgestose. Der Anstieg des Harmsäurespiegels war bei den Frauen mit

schwerer Präeklampsie sowie mit essentieller Hypertonie plus Pfropfgestose signifikant $(6.22 \mathrm{mg} \% \pm 1.30 \mathrm{mg} \%$ bzw. $6.09 \mathrm{mg} \% \pm 1.53 \mathrm{mg} \%$ ). Bei den Frauen mit leichter Präeklampsie und essentieller Hypertonie betrugen die Maxima $4.85 \mathrm{mg} \% \pm 1.34 \mathrm{mg} \%$ bzw. $4.95 \mathrm{mg} \%$ $\pm 1.22 \mathrm{mg} \%$. Bei schwerer Präeklampsie und essentieller Hypertonie plus Propfgestose war das durchschnittliche Schwangerschaftsalter bei Entbindung geringer und der Prozentsatz der Small-for-date-Kinder größer als in den beiden anderen Gruppen. Innerhalb der Gruppen gab 
es keine Korrelation zwischen Harnsäurespiegel und fetalem Gewicht.

Wir meinen, daß die Bestimmung der Harnsäure im Screening bei Schwangerschaften mit erhöhtem RR eine einfache und billige Methode darstellt, um perinatale Probleme im Zusammenhang mit einer schweren Präeklampsie zu erkennen.

Schlüsselwörter: Harnsäurespiegel, klinische Studie, Präeklampsie.

\section{Résumé}

Taux d'acide urique: une donnée utile pour déterminer la sévérité du syndrome prééclamptique et du pronostic périnatal

On a choisi les taux maximum d'acide urique sérique pendant le troisième trimestre de la grossesse chez 215 femmes enceintes hypertendues. Parmi les 215, 100 avaient une pré-éclampsie (P.E.) légère, 25 avaient une P. E. sévère, 70 présentaient une hypertension essentielle (HE) et les autres 20: HE avec PE surajoutée (HE + PE). L'augmentation des taux d'acide urique a été statistiquement significative chez les femmes avec une PE sévère $(6,22 \mathrm{mg} \% \pm 1,30 \mathrm{mg} \%)$ et chez les femmes avec HE + PE $(6,09 \mathrm{mg} \% \pm 1,53 \mathrm{mg} \%)$, comparée avec les valeurs chez les femmes atteintes d'une PE légère et $\mathrm{HE}$

Mots-clés: Acide urique, étude clinique, prééclampsie.

\section{References}

[1] Dequiedt Ph, A Tacquet, F Puech, M Cotteel, A Potier, JL Leroy, M Delacour: Valeur pronostique de l'hyperuricémie dans les hypertensions artérielles de la grossesse. A propos de 58 observations. J Gynecol Obstet Biol Reprod 8 (1979) 115

[2] Dumont M: A propos de l'hyperuricémie dans les hypertensions artérielles de la grossesse. J Gynecol Obstet Biol Reprod 8 (1979) 463

[3] FAdel HE, G Northrop, HR Misenhimer: Hyperuricemia in pre-eclampsia. Am J Obstet Gynecol 125 (1976) 640

[4] Liedholm H, S Montan, A Aberg: Risk grouping of 113 patients with hypertensive disorders during pregnancy, with respect to serum urate, proteinuria and time of onset of hypertension. Acta Obstet Gynecol Scand [Suppl] 118 (1984) 43

[5] Redman CWG, LJ Beilin, J BonNard, RH WiLKINSON: Plasma urate measurement in predicting fetal death in hypertensive pregnancy. Lancet 1 (1976) 1370
$(4,85 \mathrm{mg} \% \pm 1,34 \mathrm{mg} \%$ et $4,95 \mathrm{mg} \% \pm 1,22 \mathrm{mg} \%$ respectivement). Il a été observé une diminution remarquable de l'âge de gestation moyen au moment de l'accouchement, ainsi qu'une plus grande incidence de nouveaux-nés petits pur leur âge de gestation chez les femmes souffrant d'une $\mathrm{PE}$ sévère et de $\mathrm{HE}+\mathrm{PE}$, en comparaison avec celles avec une $\mathrm{PE}$ légère et $\mathrm{HE}$. Aucune corrélation n'a été trouvée entre les taux sériques d'acide urique et le poids fœtal dans tous les groupes.

On en déduit que la détermination du taux d'acide urique pour l'étude clinique de la grossesse, compliquée d'hypertension, est une méthode facile et de coût faible pour prédire les résultats périnatals associés à la $\mathrm{PE}$ sévère.

[6] Sagen N, K Haram, ST Nielsen: Serum urate as a predictor of fetal outcome in severe pre-eclampsia. Acta Obstet Gynecol Scand 63 (1984) 71

[7] Schuster E, B WeppelmanN: Plasma urate measurements and fetal outcome in pre-eclampsia. Gynecol Obstet Invest 12 (1981) 162

[8] SLEMONS JM, LJ BogerT: The uric acid content of maternal and fetal blood. J Biol Chem 32 (1917) 63

[9] STANDER HJ, JF CADDEN: Blood chemistry in preeclampsia and eclampsia. Am J Obstet Gynecol 28 (1934) 856

[10] VARMA TR: Serum uric acid levels as an index of fetal prognosis in pregnancies complicated by preexisting hypertension and pre-eclampsia of pregnancy. Int J Gynaecol Obstet 20 (1982) 401

Received March 20, 1987. Accepted June 29, 1987.

Dr. Liliana S. Voto

Avenida Pueyrredón 1746 2A

1119 Buenos Aires

Argentina 